\title{
RADIOCARBON AND TREE-RING DATES OF THE BES-SHATYR \#3 SAKA KURGAN IN THE SEMIRECHIYE, KAZAKHSTAN
}

\author{
Irina Panyushkina ${ }^{1}$ Fedor Grigoriev ${ }^{2}$ Todd Lange ${ }^{3}$ - Nursan Alimbay ${ }^{4}$
}

\begin{abstract}
This study employs tree-ring crossdating and radiocarbon measurements to determine the precise calendar age of the Bes-Shatyr Saka necropolis $\left(43^{\circ} 47^{\prime} \mathrm{N}, 81^{\circ} 21^{\prime} \mathrm{E}\right.$ ) built for wealthy tribe leaders in the Ili River Valley (Semirechiye), southern Kazakhstan. We developed a 218-yr tree-ring chronology and a highly resolved sequence of ${ }^{14} \mathrm{C}$ from timbers of Bes-Shatyr kurgan \#3. A 4-decadal-point ${ }^{14} \mathrm{C}$ wiggle dates the Bes-Shatyr necropolis to $600 \mathrm{cal} \mathrm{BC}$. A 47-yr range of cutting dates adjusted the kurgan date to $\sim 550 \mathrm{BC}$. This is the first result of high-resolution ${ }^{14} \mathrm{C}$ dating produced for the Saka burials in the Semirechiye. The collective dating of Bes-Shatyr indicates the early appearance of the Saka necropolis in the Semirechiye eastern margins of the Saka dispersal. However, the date is a couple of centuries younger than previously suggested by single ${ }^{14} \mathrm{C}$ dates. It is likely that the Shilbiyr sanctuary (location of the Bes-Shatyr) became a strategic and sacral place for the Saka leadership in the Semirechiye long before 550 BC. Another prominent feature of the Semirechiye burial landscape, the Issyk necropolis enclosing the Golden Warrior tomb, appeared a few centuries later according to ${ }^{14} \mathrm{C}$ dating reported by other investigators. This study contributes to the Iron Age chronology of Inner Asia, demonstrating successful results of ${ }^{14} \mathrm{C}$ calibration within the Hallstatt Plateau of the ${ }^{14} \mathrm{C}$ calibration curve. It appears that the wide range of calibrated dates for the Saka occurrences in Kazakhstan (from $800 \mathrm{BC}$ to $\mathrm{AD} 350$ ) is the result of the calibration curve constraints around the middle of the 1st millennium BC.
\end{abstract}

\section{INTRODUCTION}

In the 1950s, K A Akishev discovered a grand necropolis of 31 kurgans in a tributary valley of the Ili River and called it Bes-Shatyr. The Iliyskaya Archaeological expedition surveyed and excavated archaeological occurrences in the Semirechiye region south of Lake Balkhash between the TianShan and Altai Mountains (present-day Kazakhstan), and attributed the kurgans of Iron Age nomadic tribes to the Saka culture (Akishev and Kushayev 1963). The Semirechiye belongs to one of the most prominent sanctuaries of Saka wealthy tribes in Inner Asia. The original research on the kurgans established that a large volume of wood beams was used in the necropolis construction, which is typical for large burials of the Saka people, Indo-Europeans who inhabited Inner Asia in the 1st millennium BC (Iron Age) and spoke an Iranian language. However, to date the wood has yet to be used to develop a highly resolved radiocarbon series from the tree rings for precise dating of Saka occurrences in the Semirechiye.

Hall (1997) used calibrated ${ }^{14} \mathrm{C}$ dates from the region to tentatively date the Saka kurgans of Semirechiye between the 6th and 4th centuries BC. Previously, regional material chronologies indicated a broader range of dates for the onset of Saka culture from as early as the 8th to the 2nd centuries BC (Yablonsky 1995). The agreement of recently calibrated ${ }^{14} \mathrm{C}$ dates with other dates derived from art-historic and stylistic approaches in eastern Kazakhstan extended this dating range even further from 750 BC to AD 350. Recent success of the international "Gold of Nomads" exhibits (Chang and Guroff 2008) that included opulent golden artifacts from the exclusive Saka kurgans of the Issyk and Chilikta (or Shylikty) necropolises in eastern Kazakhstan, brought to light the problems in dating of the Saka kurgans once again.

\footnotetext{
${ }^{1}$ Laboratory of Tree-Ring Research, University of Arizona, Tucson, Arizona 85721, USA. Corresponding author. Email: ipanyush@email.arizona.edu.

${ }^{2}$ Kaz-Restoration, Almaty, 050013, Kazakhstan.

${ }^{3}$ Department of Physics, University of Arizona, Tucson, Arizona 85721, USA.

${ }^{4}$ Central State Museum of Kazakhstan, 44 Samal St., Almaty, Kazakhstan.
} 


\section{Panyushkina et al.}

The dating scheme of the Saka chronology in Kazakhstan has been under revision for the last decade (Kristiansen 2008). Nonetheless, the backbone of the Saka chronology remains the 3 necropolises: Issyk, Chilikta, and Bes-Shatyr. The Issyk kurgan (or Golden Warrior tomb) from the Talgar fluvial fan, the largest excavated kurgan in the Semirechiye, suggests the 3rd and 2nd centuries BC as a period of notable occurrence of wealthy Saka kurgans in the Semirechiye. Formerly, Akishev (1978) assigned the Issyk kurgan the 6th and 3rd centuries BC. Jacobson (1993) refers the Issyk kurgan to 4th and 3rd centuries BC and later to the 5th century BC (Chang and Guroff 2008). The latest published date was $2255 \pm 39{ }^{14} \mathrm{C}$ yr with a $2 \sigma$ calibrated interval between 400 and $200 \mathrm{BC}$ (Zaitseva et al. 2005). The date was run on wood sampled from a leg of a small portable table. North of the Semirechiye, i.e. in the Jungarskiy Alatau, the Chilikta kurgans frame the earliest appearance of the Saka nomadic nobility between the 8th and 7th centuries BC based on ${ }^{14} \mathrm{C}$ dating (Hall 1997; Panyushkina, unpublished data). Yet, the age of the Chilikta site has been recently ascribed to the 8th century BC and the 5th-2nd centuries BC (Chernikov 1975; Hall 1997; Toleubaev 2010). As for the BesShatyr necropolis, the burial objects (bronze arrowheads, in particular) date the site between the 6th and 3rd centuries BC (Akishev and Kushayev 1963). Later, the Bes-Shatyr age was narrowed to the interval of 5th to 3rd centuries BC through revision of the material chronologies (Akishev 1978). In contrast, calibrated ${ }^{14} \mathrm{C}$ dates expanded its range to between 800-750 BC (Zaitseva et al. 2005) and AD 40-420 (Hall 1997).

It was previously thought that the older kurgans of the nomadic wealthy in eastern Kazakhstan occurred in the Altai and Djungarskiy Alatau Mountains and the younger ones in the Semirechiye, southward near the Tian Shan Mountains (Chang et al. 2003). Calibration results of recent ${ }^{14} \mathrm{C}$ dates obliterated the difference in ages of these 2 regions due to the wide $2 \sigma$ calibrated intervals caused by constraints of the ${ }^{14} \mathrm{C}$ calibration curve around the middle of the 1st millennia BC (the Hallstatt Plateau). Thus, the few recent ${ }^{14} \mathrm{C}$ dates posed more questions than answers for the Saka chronology at the eastern margins of the Eurasian Steppe. This study analyzes a sequence of ${ }^{14} \mathrm{C}$ dates from tree rings of the Bes-Shatyr kurgan \#3 with an emphasis on precisely estimating absolute age of the kurgan by a best match to the IntCal09 calibration curve and suggests an absolute calendar date of the Bes-Shatyr necropolis.

\section{MATERIAL AND METHODS}

Bes-Shatyr kurgan \#3 $\left(43^{\circ} 47^{\prime} \mathrm{N}, 81^{\circ} 21^{\prime} \mathrm{E}\right)$ is a part of the Bes-Shatyr necropolis located on the east bank of the Ili River just outside of Shilbiyr Gorge, Ile-Alatauskiy National Park. The Bes-Shatyr necropolis is a group of 31 kurgans stretching along a 2-km semidesert terrain and organized in southern and northern rows $\sim 500 \mathrm{~m}$ apart. The northern row incorporates 4 large kurgans including the studied kurgan \#3, which is the second largest kurgan in the group, sited next to the largest kurgan of the necropolis (the Great kurgan: $104 \mathrm{~m}$ base diameter and $15 \mathrm{~m}$ height). The base diameter of kurgan \#3 is $75 \mathrm{~m}$, its height is $11.5 \mathrm{~m}$ (equal to a 3-story building). The complex structure of kurgan \#3 was built from 17 stone-earthen layers walled with stones. It had a wooden tomb erected above the ground with a grid of underground passages. The tomb has been burned down sometime before construction of the burial mound. The tomb looked like a well-built large long house. All beams used in the tomb construction had been wood-worked. The studied specimens had partially burned or removed sapwood, but the outermost rings representing the cutting dates survived in the beams along some parts of the tree circumference. Massive beams had a pair of round cut-through handles near the ends to tie a rope for ease of transport. Unfortunately, as is frequently the case, most of the tomb timbers were lost after excavation or were reburied on the site. 
Five cross-sections were collected from the tomb remnants during clean-up of the kurgan by the KAZ-Restoration development project in 2011-2012. The tree rings were crossdated using tree-ring width series measured and overlapped with TSAP software (Rinn 2003). Four consecutive subsamples of 10-yr ring groups were cut from burned specimen \#1 (Figure 1). The tree-ring subsamples were ground to 20-mesh and initially converted to holocellulose by the Jayme-Wise method modified after Leavitt and Danzer (1993). At the Laboratory of Tree-Ring Research (University of Arizona), the powdered wood was first extracted with toluene/ethanol and then with ethanol organic solvents in a Soxhlet extraction apparatus, followed by boiling in deionized water. Samples were delignified in an acetic acid-acidified, sodium chlorite aqueous solution at $70^{\circ} \mathrm{C}$, and then thoroughly rinsed in deionized water. Combustion to $\mathrm{CO}_{2}$, graphite conversion, and ${ }^{14} \mathrm{C}$ measurements using accelerator mass spectrometry were completed at the Arizona NSF Accelerator facility. The ${ }^{14} \mathrm{C}$ dates were calibrated with CALIB 6.0 software (http://calib.qub.ac.uk/calib/) and the IntCal09 data set (Reimer et al. 2009).

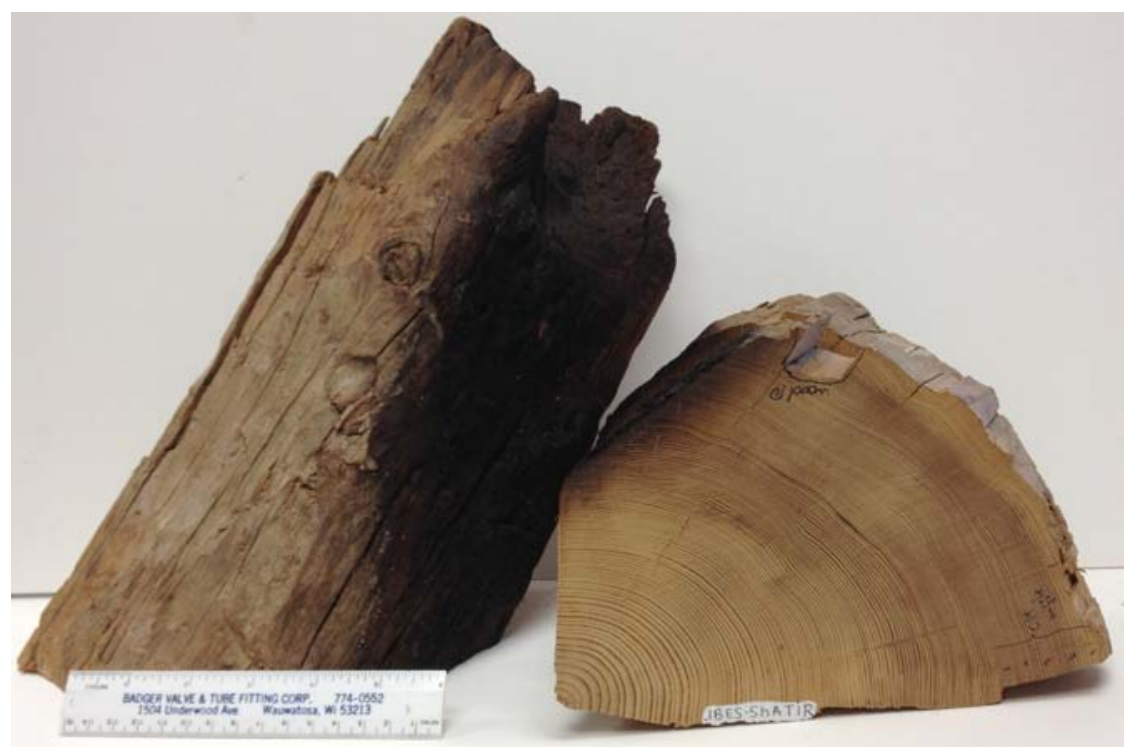

Figure 1 Photo of wood specimen $\# 1$ subsampled for ${ }^{14} \mathrm{C}$ dating. The charred end is the result of a fire that occurred in the Bes-Shatyr \#3 tomb around the time of construction.

\section{RESULTS AND DISCUSSION}

Five collected specimens were identified as spruce (Picea smithiana), presently growing about 200$250 \mathrm{~km}$ away (the Zailiyskiy Alatau Range) from the semidesert archaeological site. The relatively large number of tree rings per specimen (179-211 rings), very slow rate of radial growth, and high cross-correlation of the 5 studied specimens $(r=0.56 ; p>0.01)$ suggest that the mature trees came from the same location and grew under severe stress of external growth-limiting factors. Five crossdated tree-ring width series overlapped into a 218-yr floating chronology (Figure 2) with the following range of the wood cutting dates: years 184, 210, 211, 216, and 217. The difference between the most recent cutting date (specimen \#3) of the tree-ring chronology and the outermost ring of specimen \#1 from which the ${ }^{14} \mathrm{C}$ date was obtained is $33 \mathrm{yr}$. An extra 13 rings were added between the ${ }^{14} \mathrm{C}$-dated ring of sample \#1 and the outside date of the specimen (rings 157-166 of the master treering chronology). Consequently, a total of 47 rings are applied to correct the calendar age of kurgan resulting from calibration of the Bes-Shatyr- $3{ }^{14} \mathrm{C}$ wiggle. 


\section{Panyushkina et al.}

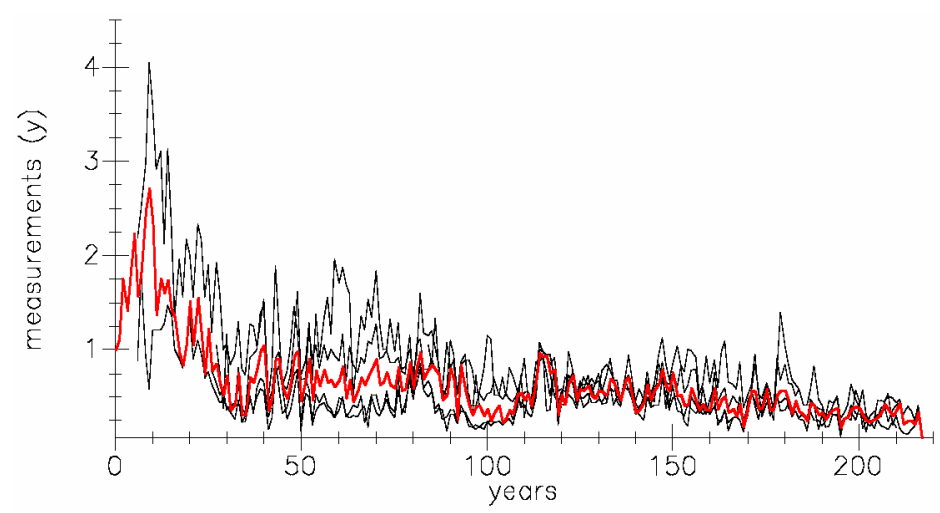

Figure 2 Crossdated tree-ring width series and their mean (thick line) measured from 5 tree-ring specimens of the Bes-Shatyr kurgan \#3 timbers. The span of cut dates is $33 \mathrm{yr}$. The ${ }^{14} \mathrm{C}$ dates were run on the interval from ring \#127 to ring \#166 of the chronology.

Four ${ }^{14} \mathrm{C}$ dates measured on a 40-calendar-year interval of the Bes-Shatyr kurgan \#3 tree-ring series (Table 1) fell into a 63-yr interval between 2527 and $2464{ }^{14} \mathrm{C}$ BP, indicating low variability of the ${ }^{14} \mathrm{C}$ curve in the period of interest. The error of ${ }^{14} \mathrm{C}$ age estimation varies from 37 to $43 \mathrm{yr}$, which is comparable to other existing ${ }^{14} \mathrm{C}$ measurements for the Bes-Shatyr necropolis. The average ${ }^{14} \mathrm{C}$ age of the 4 outer decades is $2490{ }^{14} \mathrm{C}$ yr BP. This date is younger than 3 single ${ }^{14} \mathrm{C}$ dates run on wood from kurgans \#1, \#3, and kurgan \#6 of the Bes-Shatyr necropolis previously reported by other studies (Dolukhanov et al. 1970; Zaitseva et al. 2005). Nevertheless, the ordering of the ${ }^{14} \mathrm{C}$ dates should be considered with caution for interpretations of the necropolis chronology because the other ${ }^{14} \mathrm{C}$ dates are problematic. The oldest ${ }^{14} \mathrm{C}$ measurement on a fragment of a wooden craft object from kurgan \#6 published by Zaitseva et al. (2005) was $2570 \pm 35{ }^{14} \mathrm{C}$ BP (LE-5643). The date calibrates between 820 and $750 \mathrm{cal}$ BC $(2 \sigma)$. This old date does not represent the chronology of this kurgan well due to the obvious old-wood effect, but places a possible uppermost margin of the necropolis construction. Two other ${ }^{14} \mathrm{C}$ dates on wood submitted by Akishev and published by Dolukhanov et al. (1970) were $2550 \pm 65{ }^{14} \mathrm{C}$ BP from kurgan \#1 (LE-603) and $1850 \pm 70{ }^{14} \mathrm{C}$ BP from kurgan \#3 (LE-590). The calibrated interval is $820-490$ cal BC $(2 \sigma)$ for kurgan \#1 and 340 cal BC-cal AD 5 $(2 \sigma)$ for kurgan \#3. The type of wood is unknown in both cases. The kurgan \#1 date (Dolukhanov et al. 1970) is similar in age to kurgan \#6 (Zaitseva et al 2005), but the kurgan \#3 date (Dolukhanov et al. 1970) is too young for the studied kurgan group $\left(\sim 700{ }^{14} \mathrm{C}\right.$ yr younger) and not reliable for the dating. The updated and revised IntCal09 calibration data set used in CALIB 6.0 suggests little difference in the calibrated intervals used here and by Hall (1997). It is conceivable that kurgan \#1 and kurgan \#6 predate kurgan \#3.

The 4-point ${ }^{14} \mathrm{C}$ wiggle sequence of the Bes-Shatyr kurgan \#3 fits well to the shape of the linear calibration curve ending at $\sim 600 \mathrm{cal} \mathrm{BC}$ (Figure 3). All 4 measurements clearly emerge before the first peak of the ${ }^{14} \mathrm{C}$ Hallstatt Plateau. Adding the $47 \mathrm{yr}$ omitted from the ${ }^{14} \mathrm{C}$ dating to the calibrated ${ }^{14} \mathrm{C}$ date suggests $~ 550 \mathrm{BC}$ as the occurrence date of kurgan \#3 at the Bes-Shatyr necropolis. Originally, the age and cultural identity of the Bes-Shatyr necropolis was determined using burial complexes of small kurgans of the cemetery because the large excavated kurgans of the site (\#1, 2, 3, 6, 8, and the Great kurgan) were completely robbed in ancient times and the tomb of kurgan \#3 was burned down before it had been covered with the earthen mound. Customarily, the smaller kurgans are added later to a noble cemetery. Kurgan \# 25 (base diameter $8.5 \mathrm{~m}$ and $1 \mathrm{~m}$ high) provided material objects (e.g. 


\section{${ }^{14} \mathrm{C}$ and Tree-Ring Dates of the Bes-Shatyr \#3}

wooden parts of armory, belt buckles, and bronze arrowheads) that date the cemetery to the 5th-3rd centuries BC (Akishev and Kushayev 1963). It is worth noting that the upper range of the stylistic dating corresponds well to the result from the highly resolved ${ }^{14} \mathrm{C}$ dating.

Table $1{ }^{14} \mathrm{C}$ ages of decadal ring groups from wood specimen \#1 used in wiggle-matching (Bronk Ramsey et al. 2001) (Figure 3). Holocellulose pretreatment was done in the LTRR chemical Lab. Note: Column 3 gives the ring count of the tree-ring specimen, not the master tree-ring chronology. The ${ }^{14} \mathrm{C}$ sequence contains consistent measurements with no suspected outliers.

\begin{tabular}{llllll}
\hline Sample ID & Lab ID & Ring \# & $\delta^{13} \mathrm{C}$ & Fm & ${ }^{14} \mathrm{C}$ yr BP \\
\hline Bes-5 & AA \#97421 & $121-130$ & -20.2 & $0.7357 \pm 0.0034$ & $2465 \pm 37$ \\
Bes-4 & AA \#97420 & $131-140$ & -20.0 & $0.7321 \pm 0.0039$ & $2504 \pm 43$ \\
Bes-3 & AA \#97419 & $141-150$ & -20.4 & $0.7301 \pm 0.0035$ & $2527 \pm 38$ \\
Bes-2 & AA \#97418 & $151-160$ & -20.5 & $0.7358 \pm 0.0036$ & $2464 \pm 39$ \\
\hline
\end{tabular}

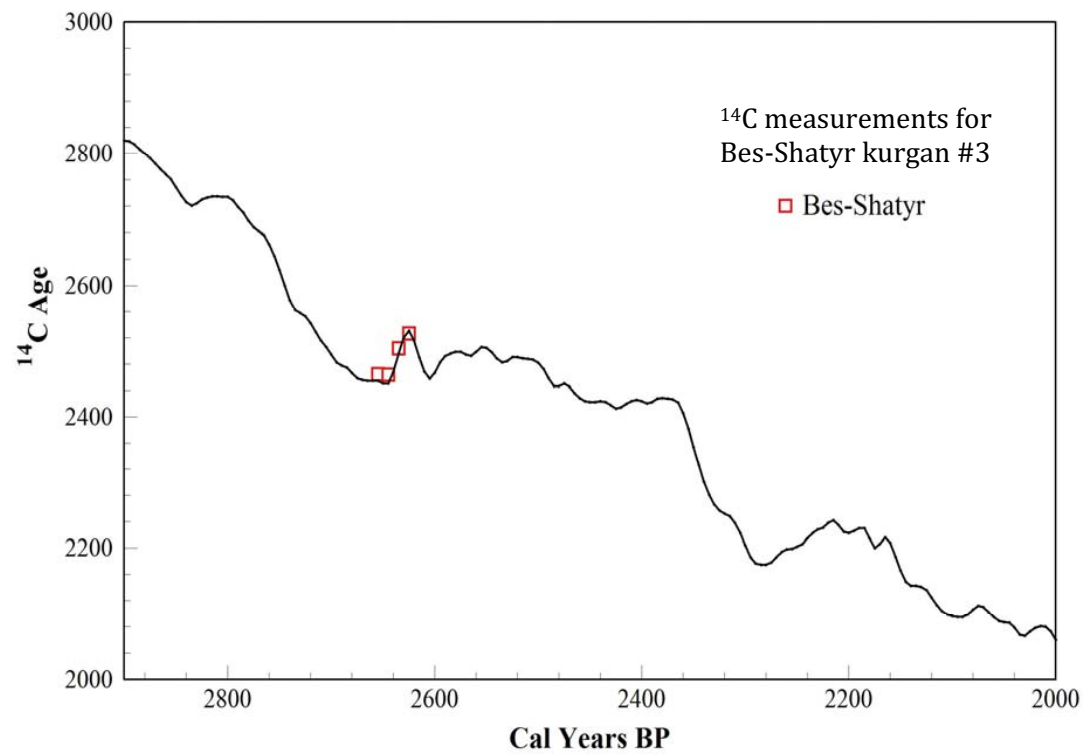

Figure 3 High-resolution ${ }^{14} \mathrm{C}$ calibration of the tree-ring sequence for Bes-Shatyr kurgan \#3. The plot shows the best visual fits of ${ }^{14} \mathrm{C}$ dates with the IntCal09 calibration curve (Reimer et al. 2009).

Calibration of single ${ }^{14} \mathrm{C}$ dates from the Bes-Shatyr necropolis produces ambiguous results. It has not yet been feasible to achieve precise dating of Saka occurrences with a single ${ }^{14} \mathrm{C}$ measurement. The challenging features of the calibration curve shape during the middle of the 1st millennium $\mathrm{BC}$ produce large offsets in calibrated calendar ages. Figure 4 demonstrates the enormous multicentury calibration intervals $\left(1\right.$ and $2 \sigma$ ) for a ${ }^{14} \mathrm{C}$ single measurement of a 10 -yr tree-ring group used for the development of the highly resolved ${ }^{14} \mathrm{C}$ series for kurgan \#3 (see last 2 dates in Table 1 ). In this case, the accuracy of calibrated dates does not depend on the precision of ${ }^{14} \mathrm{C}$ measurements either. A measurement with a 39-yr error may fall into the same calibrated interval as a measurement with a 75yr error (see calibration results of kurgan \#1 above). It appears that multiple ${ }^{14} \mathrm{C}$ measurements of the same sample with a known chronological order of subsamples (e.g. like tree rings) increase the accuracy of dating of the Saka kurgans. Another way to determine the order and precise age of other large 


\section{Panyushkina et al.}

kurgans from the Bes-Shatyr necropolis is dendrochronological dating. Analysis of small pieces of wood ( $<50$ rings) collected at kurgan \#6 indicates that wood of spruce with highly sensitive tree rings was used in construction of this kurgan as well. Any spruce wood from Saka kurgans of the Semirechiye, which most likely date to the middle of the 1st century BC, could potentially be suitable for crossdating. The developed master tree-ring chronology of kurgan \#3 spans from 730 to 550 BC as determined with the highly resolved ${ }^{14} \mathrm{C}$ series of that kurgan.
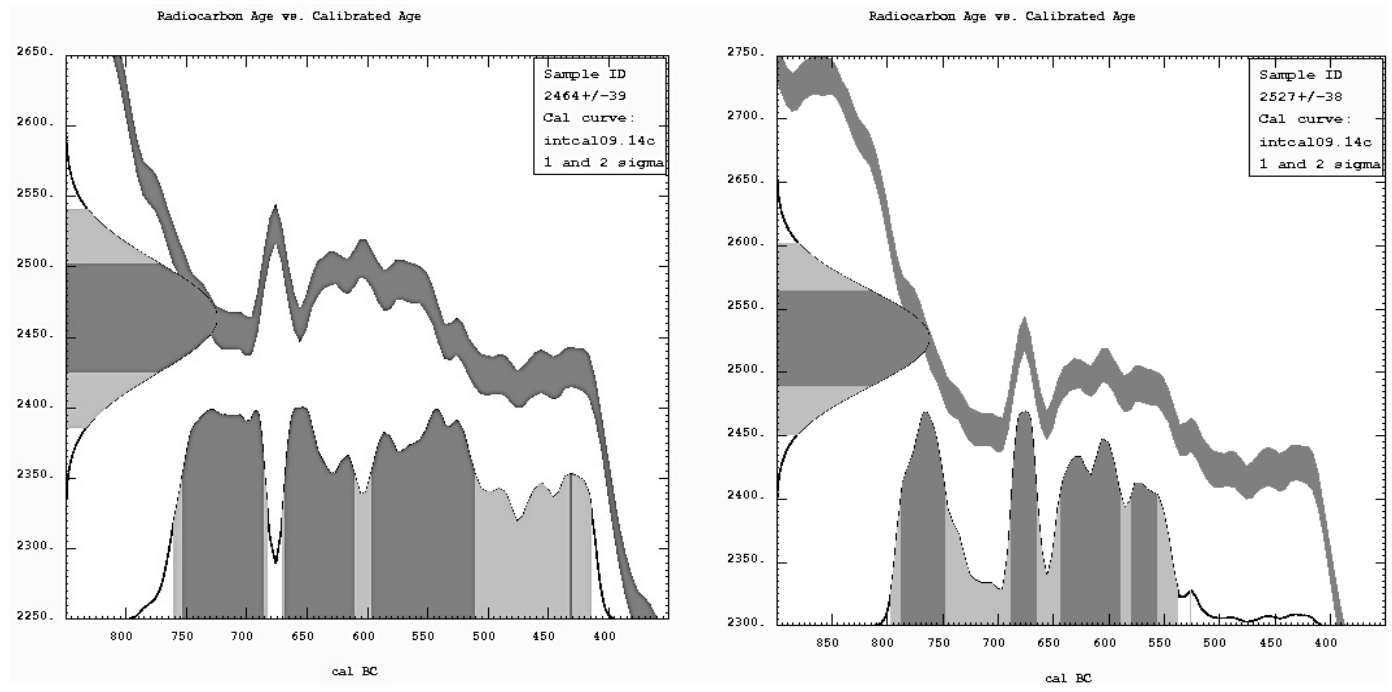

Figure 4 Two examples of calibration results of a single ${ }^{14} \mathrm{C}$ date measured on outer tree rings of the studied kurgan \#3 wood specimen (Table 1). The displayed wide range of calendar intervals is caused by the Hallstatt Plateau, a relatively flat period in the calibration curve between 800 and 400 BC.

In conclusion, we believe that the collective dating of the Bes-Shatyr suggests that the Bes-Shatyr wealthy kurgans were erected from 750 to $550 \mathrm{BC}$. It is possible that kurgan \#3, dated to $550 \mathrm{BC}$, is the latest kurgan constructed at the Bes-Shatyr necropolis. Bes-Shatyr appears to be the oldest wealthy burial site in the Semirechiye as determined by precise ${ }^{14} \mathrm{C}$ dating. The site is $200-250 \mathrm{yr}$ younger than it was determined with single ${ }^{14} \mathrm{C}$ dates previously. This eliminates the huge gap between erection of the Issyk and Bes-Shatyr burial grounds-the 2 most prominent excavated sites of Saka culture in the Semirechiye. The Bes-Shatyr kurgan \#3 (Semirechiye West) preceded the elite burials of Saka from the Issyk (Semirechiye East) by about 150 yr.

Tree rings from the wooden burial structures of Saka are a tremendous asset for refining the dynamic history of nomadic tribes during the 1st millennium BC. Additional highly resolved ${ }^{14} \mathrm{C}$ records from tree rings are in great demand for reconstructing the spatial/temporal patterns of Saka culture in the Semirechiye and Inner Asia. Furthermore, there can be no comprehensive understanding of Saka interactions with ancient people of the neighboring regions of modern Mongolia, Siberia, China (e.g. Xinjiang and Tarim Basin), Afghanistan, and Uzbekistan unless the ${ }^{14} \mathrm{C}$ dates can be resolved within the Hallstatt Plateau of the ${ }^{14} \mathrm{C}$ calibration curve. 
${ }^{14} \mathrm{C}$ and Tree-Ring Dates of the Bes-Shatyr \#3

\section{ACKNOWLEDGMENTS}

Alex Wiedenhoeft at the USDA Forest Product Lab (Madison, Wisconsin, USA) provided wood identification and S W Leavitt at the University of Arizona Lab of Tree-Ring Research assisted in wood cellulose extraction. This work was funded through NSF \#BCS 1122398 award.

\section{REFERENCES}

Akishev KA. 1978. Kurgan Issyk. Moscow: Iskusstvo. In Russian. Akishev KA, Kushayev GA. 1963. Ancient Culture of Sakas and Wusuns in the Ili River Valley. Alma-Ata: Kazakh SSR Academy of Sciences. In Russian.

Bronk Ramsey C, van der Plicht J, Weninger B. 2001. 'Wiggle matching' radiocarbon dates. Radiocarbon 43(2A):381-9.

Chang C, Norbert B, Grigoriev F, Rosen AM, Tourtellotte PA. 2003. Iron Age society and chronology in south-east Kazakhstan. Antiquity 77(296):298-312.

Chang C, Guroff KS, editors. 2008. Of Gold and Grass: Nomads of Kazakhstan. Oakville: Mosaic. 180 p.

Chernikov SS. 1975. K voprosu o khronologicheskikh periodakh v epokhu rannikh kochevnikov [A question on the chronological periods of the Early Nomads Epoch]. Pervobytnaya arkheologiya Sibiri [Primordial Archaeology of Siberia]. In Russian.

Dolukhanov PM, Romanova YN, Semyontsov AA. 1970. Radiocarbon dates of the Institute of Archaeology II. Radiocarbon 12(1):130-55.

Hall ME. 1997. Towards an absolute chronology for the Iron Age of Inner Asia. Antiquity 71(274):863-74.

Harmatta J. 1999. History of Civilization of Central Asia. Volume 2. Motilal Banarsidass. 421 p.

Jacobson E. 1993. The Deer-Goddess of Ancient Siberia: A Study in the Ecology of Belief. Leiden: E J Brill. 269 p.

Kristiansen K. 2008. Eurasia in the Bronze and early Iron Ages. Antiquity 82(318):1113-8.
Leavitt SW, Danzer SR. 1993. Method for batch processing small wood samples to holocellulose for stable carbon isotope analysis. Analytical Chemistry 65(1): 87-9.

Reimer PJ, Baillie MGL, Bard E, Bayliss A, Beck JW, Blackwell PG, Bronk Ramsey C, Buck CE, Burr GS, Edwards RL, Friedrich M, Grootes PM, Guilderson TP, Hajdas I, Heaton TJ, Hogg AG, Hughen KA, Kaiser KF, Kromer B, McCormac G, Manning S, Reimer RW, Richards DA, Southon JR, Talamo S, Turney CSM, van der Plicht J, Weyhenmeyer CE. 2009. IntCal09 and Marine09 radiocarbon age calibration curves, 0-50,000 years cal BP. Radiocarbon 51(4): 1111-50.

Rinn F. 2003. Time Series Analysis and Presentation Software (TSAP-Win). User Reference (Version 0.53). RinnTech, Heidelberg, Germany.

Toleubaev A. 2010. Snow leopards, eagle-felines, and golden deer. Treasures from the hill of horse races. In: Chang C, Guroff KS, editors. Of Gold and Grass: Nomads of Kazakhstan. Oakville: Mosaic. p 51-7.

Yablonsky LT. 1995. The material culture of the Saka and historical reconstruction. In: Davis-Kimball J, Bashilov VA, Yablonsky LT, editors. Nomads of the Eurasian Steppe in the Early Iron Age. Berkeley: Zinat Press. p 201-35.

Zaitseva GI, Bokovenko NA, Alekseev AY, Chugunov KV, Scott EM, editors. 2005. Eurasia in Scythian time: Radiocarbon and Archaeological Chronologies. St. Petersburg: Thesa. In Russian. 